\title{
Pengelolaan Limbah B3 di Rumah Sakit Gigi dan Mulut Universitas Padjadjaran Kota Bandung
}

\author{
Eka Wardhani $^{1 *}$, Fitra Akbar Kamil ${ }^{2}$ \\ ${ }^{1,2}$ Jurusan Teknik Lingkungan, Institut Teknologi Nasional, Bandung \\ *Korensponden email: ekawardhani08@gmail.com
}

Diterima: 12 Oktober 2020

Disetujui: 26 Oktober 2020

\begin{abstract}
This study aims to identify and evaluate the management of toxic and hazardous materials (THM) at Universitas Padjadjaran (Unpad) Dental Hospital. This hospital is a special teaching hospital to support the teaching and learning process at the Faculty of Medicine Unpad. Based on the results of observations, THM were produced as much as $322.96 \mathrm{~kg} /$ month. The waste generation includes infectious, sharp objects and pharmaceutical waste. The research was conducted by using a comparison method between the conditions at the research location and the applicable regulations. Based on the results of research, the Dental and Oral Hospital Unpad has carried out the management of THM in accordance with applicable regulations. There are several aspects that must be improved, namely the process of sorting and packaging of THM, and attaching symbols and labels to containers. Temporary shelters for THM are operating properly according to the criteria, but there are several things that need to be improved, namely routinely replacing damaged labels because they can cause misinformation about these THM. Shelters need to be equipped with cooling devices, improve ventilation, and establish good trench drainage while THM increasing.
\end{abstract}

Keywords: Universitas Padjadjaran, hazardous material, waste management, dental hospital, Bandung

\begin{abstract}
Abstrak
Penelitian ini bermaksud untuk mengidentifikasi dan mengevaluasi pengelolaan Limbah B3 (LB3) di RS Gigi dan Mulut (RSGM) Universitas Padjadjaran (Unpad) Bandung. Rumah sakit ini merupakan rumah sakit pendidikan khusus untuk mendukung proses belajar mengajar di Fakultas Kedokteran Unpad. Berdasarkan hasil observasi LB3 yang dihasilkan sebanyak 322,96 kg/bulan. Timbulan limbah tersebut meliputi limbah infeksius, benda tajam dan farmasi. Penelitian dilakukan dengan metode perbandingan antara kondisi di lokasi penelitian dengan peraturan yang berlaku. Berdasarkan hasil penelitian pihak RSGM Unpad telah melakukan pengelolaan LB3 sesuai dengan peraturan yang berlaku. Terdapat beberapa aspek yang harus disempurnakan yaitu proses pemilahan dan pewadahan LB3 dan pelekatan simbol dan label pada wadah. TPS LB3 sudah beroperasi dengan baik sesuai dengan kriteria, tetapi terdapat beberapa hal yang perlu ditingkatkan yaitu secara rutin melakukan penggantian label yang rusak karena dapat menyebabkan kesalahan informasi mengenai LB3 tersebut. TPS B3 perlu dilengkapi dengan alat pendingin, memperbaiki ventilasi, dan membangun saluran drainase yang baik.
\end{abstract}

Kata Kunci: Universitas Padjadjaran, B3, pengelolaan limbah, RS Gigi dan Mulut, Bandung

\section{Pendahuluan}

Rumah sakit (RS) merupakan fasilitas kesehatan pokok yang harus ada di setiap wilayah dengan tujuan utama untuk pengobatan dan meningkatkan kesehatan masyarakat, RS juga merupakan tempat untuk pendidikan dan pelatihan bagi tenaga kesehatan seperti dokter, perawat, ahli farmasi serta petugas medis lainnya [1]. RS merupakan fasilitas kesehatan yang memiliki sifat khusus, dimana perkembangannya dipengaruhi oleh kemajuan ilmu pengetahuan dan teknologi. Hal lain yang mempengaruhi kemajuan RS yaitu perubahan kondisi kehidupan sosial, ekonomi, budaya dan kesehatan masyarakat. Pelayanan RS terdiri dari ruang rawat inap, rawat jalan, instalasi gawat darurat, laboratorium dan sarana rehabilitasi penunjang medis. Tujuan pembangunan RS sebagai sarana pengobatan untuk menyembuhkan masyarakat yang menderita penyakit tertentu [2]. RS pendidikan merupakan sarana penunjang proses belajar dan mengajar Fakultas Kedokteran. RS pendidikan merupakan sarana pendidikan, penelitian, dan pelayanan kesehatan secara komprehensif dalam bidang pendidikan kedokteran, baik kedokteran umum, gigi, jenjang pendidikan lanjutan, dan profesi [3].

RS merupakan salah satu sarana yang menjadi sumber penghasil limbah bahan beracun dan berbahaya (LB3). LB3 yang tidak dikelola dengan baik akan menimbulkan masalah lingkungan karena 
sifat LB3 yang beracun, mengandung bahan kimia berbahaya, mudah meledak, mudah bereaksi, korosif, dan mengandung kuman penyakit (infeksius). LB3 yang dihasilkan dari kegiatan RS bersifat infeksius, mengandung bahan kimia, radioaktif yang dihasilkan dari operasional rumah sakit yang berasal dari instalasi kesehatan, fasilitas penelitian, dan laboratorium. Bentuk limbah yang dihasilkan berupa padat, cair, pasta (gel) maupun gas [4].

Menurut Keputusan Menteri Kesehatan Republik Indonesia Nomor 1.204 Tahun 2004 (Kepmen RI No 1.204/2004) tentang Persyaratan Kesehatan Lingkungan Rumah Sakit, menjelaskan bahwa limbah RS merupakan semua limbah yang ditimbulkan dari kegiatan RS yang terdiri dari limbah medis padat dan non-medis. Kedua jenis limbah tersebut perlu dilakukan pengelolaan dengan baik, terutama limbah padat medis yang termasuk ke dalam kategori LB3 karena bersifat infeksius [5][6][7]. Rumah Sakit Gigi dan Mulut Universitas Padjadjaran (RSGM Unpad) adalah rumah sakit Tipe A yang berada di Jalan Sekeloa Selatan Bandung. RS ini memiliki dental unit sebanyak 264 buah, 11 tempat tidur rawat inap, serta pelayanan di 19 instalasi [8]. Aktivitas RS ini menghasilkan limbah yang termasuk LB3 dan non LB3 bagi manusia dan lingkungan sekitar. Upaya peningkatan kesehatan dan keselamatan pasien, pekerja, masyarakat sekitar serta lingkungannya maka perlu dilakukan evaluasi mengenai tata cara pengelolaan LB3 dengan mengacu pada Peraturan Menteri Lingkungan Hidup dan Kehutanan Republik Indonesia Nomor 56 Tahun 2015 (PermenLHK No 56/2015) tentang tata cara dan persyaratan teknis pengelolaan LB3 dari fasilitas pelayanan kesehatan.

Penelitian ini bermaksud untuk mengidentifikasi timbulan serta mengevaluasi pengelolaan LB3 di RSGM Unpad guna meningkatkan kualitas lingkungan di RS tersebut. Tujuan penelitian, yaitu (1) mengidentifikasi LB3 di RSGM Unpad, (2) membandingkan dan mengevaluasi pengelolaan LB3 dengan Permen LHK No 56/2015, dan (3) memberi rekomendasi pengelolaan LB3. Ruang lingkup dalam penelitian ini yaitu limbah yang dianalisis merupakan limbah padat medis yang berasal dari pelayanan dan penunjang medis. Evaluasi berdasarkan beberapa aspek teknis, yaitu pemilahan, penyimpanan, pengumpulan, dan pengangkutan. LB3 padat medis yang dievaluasi adalah limbah infeksius dan limbah benda tajam.

\section{Metode Penelitian}

Penelitian diawali dengan studi literatur dan selanjutnya pengambilan data dari jurnal, buku, dan literatur yang berkaitan dengan pengelolaan LB3 yang dihasilkan dari aktivitas RS. Langkah selanjutnya yaitu penghimpunan data sekunder dan primer. Pengumpulan data sekunder berupa pengambilan data berupa gambaran umum, kegiatan, timbulan serta pengelolaan LB3 di RSGM Unpad. Data primer diperoleh melalui observasi lapangan serta wawancara secara mendalam dengan pihak pengelola LB3. Pengolahan data merupakan penyusun data yang diperoleh secara sistematis, dilakukan dengan melakukan modifikasi dan pengecekan kelengkapan data menjadi lebih mudah dipahami untuk dilakukan analisis dan pembahasan data yang sudah didapatkan. Pengolahan data dilakukan secara deskriptif dengan membandingkan antara peraturan yang berlaku dengan pengelolaan LB3 di RSGM Unpad. Peraturan yang dirujuk dalam penelitian ini yaitu:

1. Permen LHK No 56/2015 tentang Tata Cara dan Persyaratan Teknis Pengelolaan LB3 dari fasilitas pelayanan kesehatan.

2. Keputusan Kepala Badan Pengendalian Lingkungan (Bapedal) No. KEP-01/BAPEDAL/09/1995

Tentang Tata Cara dan Persyaratan Teknis Penyimpanan dan Pengumpulan LB3

3. Permen LHK No 02/2008 tentang Pemanfaatan LB3

4. Permen LHK No 14/2013 tentang Simbol dan Label LB3

\section{Hasil dan Pembahasan}

Fakultas Kedokteran Gigi (FKG) Unpad berdiri pada tahun 1959 dengan kampus pertama berlokasi di Jalan Cisangkuy 4 Bandung. Tahun 1969 kampus FKG Unpad dipindahkan ke Jalan Maulana Yusuf 12 Bandung dan pada Tahun 1979 Kampus FKG Unpad kembali pindah ke tempat yang baru yaitu Jalan Sekeloa Selatan I Bandung. RSGM Unpad adalah rumah sakit Tipe A yang memiliki 3 lantai dimana lantai satu dan dua digunakan sebagai ruang tindakan pelayanan medis dan lantai tiga sebagai ruang rawat inap dan ruang direktur beserta stafnya. RSGM Unpad memiliki dental unit sebanyak 264 buah, ruang rawat inap dengan 8 unit tempat tidur, serta pelayanan di 19 instalasi. RSGM Unpad memiliki fasilitas pelayanan medis, yaitu instalasi umum dan gawat darurat umum, ruang perawat umum (poli gigi umum), ruang special dental care (SDC), poli gigi spesialistik, bedah sentral, dan radologi. Pelayanan rawat jalan yaitu untuk pelayanan kedokteran gigi anak, dan pelayanan ruang rawat inap. Kegiatan penunjang nonmedis meliputi ruang sampling, ruang assesment, ruang laktasi, nurse station, ruang dokter, ruang 
istirahat dokter jaga, ruang depo farmasi, ruang janitor, ruang tunggu pasien, ruang direksi, ruang administrasi, ruang manajemen, ruang rapat, ruang tidur dokter jaga, ruang baca, ruang tunggu keluarga pasien, laundry, pantry, toilet, dan gudang sarana dan prasarana. RSGM Unpad merupakan RS Gigi dan Mulut rujukan masyarakat khususnya di wilayah Kota Bandung dan Provinsi Jawa Barat pada umumnya [8].

Sistem pengelolaan di LB3 di RSGM Unpad dibedakan berdasarkan karateristiknya. Pewadahan limbah menjadi dua tempat dimana limbah infeksius dimasukan ke dalam wadah berwarna kuning memiliki logo infeksius dan limbah-limbah benda tajam hasil, benang operasi, suntikan dan limbah hasil operasi dimasukan kedalam safetybox. Limbah tersebut dikumpulkan di Tempat Pembuangan Sementara (TPS) LB3 setiap sore hari. Pengangkutan LB3 dijadwalkan seminggu dua kali pada hari Senin dan Kamis oleh perusahaan swasta pengelola LB3 yaitu PT. Jasa Medivest. Perusahaan ini merupakan anak perusahaan PT. Jasa Sarana, yang melayani pengelolaan limbah medis khususnya RS. Perusahaan ini beroperasi sejak 2009 yang merupakan satu-satunya perusahaan pengelolaan LB3 di Indonesia yang fokus pada usaha jasa pengelolaan limbah medis. Perusahaan ini telah memiliki sertifikat ISO 9001 tentang sistem manajemen mutu, ISO 14001 tentang sistem manajemen lingkungan, dan ISO 18001 tentang Occupational Health and Safety Assessment Series. Perusahaan ini juga memegang penghargaan Proper biru dari KLHK untuk penataan lingkungan. Berkaitan dengan komitmen dari perusahaan pengelolaan LB3 yang sangat baik maka pihak RSGM Unpad memberikan kepercayaan penuh untuk mengelola LB3 dari aktivitasnya kepada perusahaan tersebut [8].

\section{Identifikasi Sumber Penghasil dan Timbulan Limbah Padat Medis}

Berdasarkan hasil observasi RSGM Unpad menghasilkan dua jenis LB3 yaitu limbah infeksius yang disimpan pada tempat sampah berwarna kuning dan benda tajam yang disimpan pada safetybox. Timbulan LB3 medis dihasilkan oleh pasien, dokter, dan asisten dokter di RSGM Unpad. Berdasarkan data yang didapat timbulan limbah padat medis di RSGM Unpad rata-rata setiap bulan sebanyak 322,96 $\mathrm{kg}$. Timbulan LB3 tersebut meliputi limbah infeksius, benda tajam dan farmasi. Tabel 1 menyajikan identifikasi sumber LB3 di RSGM Unpad.

Prinsip penanganan LB3 medis yang harus diperhatikan berdasarkan peraturan yang berlaku yaitu: (a) LB3 medis ditempatkan dalam tempat yang sesuai dengan kategori limbah, tempat dapat berupa wadah atau kantong yang dipisahkan antara beberapa LB3 yang dihasilkan; (b) jumlah LB3 yang dikumpulkan dalam wadah maksimal 75 persen volume wadah; (c) penanganan LB3 harus dilakukan secara khusus supaya tidak terjadi kecelakaan kerja seperti tertusuk atau terluka akibat benda tajam yang dihasilkan. Limbah benda tajam harus dipisahkan pada tempah khusus; (d) tidak boleh melakukan penekanan atau pemadatan LB3 dengan menggunakan tangan atau kaki harus menggunakan alat khusus; (e) LB3 tidak boleh ditangani secara manual harus menggunakan peralatan khusus; dan (f) penggunaan wadah atau kantong LB3 harus dipasang dua lapis untuk menghindari terjadinya kebocoran, robek atau LB3 tidak tertutup sempurna. Ke-lima prinsip penanganan LB3 tersebut bertujuan untuk melindungi pekerja supaya tidak kena kerugian dari LB3 yang ditanganinya [9-14].

Tabel 1. Identifikasi sumber penghasil LB3 di RSGM Unpad

\begin{tabular}{|c|c|c|c|c|}
\hline No & $\begin{array}{l}\text { Jenis } \\
\text { Limbah } \\
\text { Padat }\end{array}$ & Karakteristik Limbah & Sumber Limbah & Keterangan \\
\hline 1. & Infeksikus & $\begin{array}{l}\text { Terinfeksi mikroorganisme } \\
\text { yang berasal dari kapas, } \\
\text { perban, bekas perawatan gigi } \\
\text { dan mulut pasien }\end{array}$ & $\begin{array}{l}\text { Ruang perawat, intensif } \\
\text { poliklinik dan ruang } \\
\text { operasi, ruang co-assistant } \\
\text { dokter }\end{array}$ & $\begin{array}{l}\text { Limbah terdiri dari } \\
\text { kapas, perban, } \\
\text { masker, sarung tangan, } \\
\text { perlak }\end{array}$ \\
\hline 2. & $\begin{array}{l}\text { Benda } \\
\text { tajam }\end{array}$ & $\begin{array}{l}\text { Berpotensi menyebabkan } \\
\text { cedera, sobekan/tusukan, } \\
\text { infeksi dapat terkontaminasi, } \\
\text { dan beracun }\end{array}$ & $\begin{array}{l}\text { Ruang perawat, intensif } \\
\text { poliklinik dan ruang } \\
\text { operasi, ruang co-assistant } \\
\text { dokter }\end{array}$ & $\begin{array}{l}\text { Limbah berupa jarum } \\
\text { suntik, jarum infus, } \\
\text { botol obat yang telah } \\
\text { kosong semuanya } \\
\text { disimpan pada safety } \\
\text { box }\end{array}$ \\
\hline 3. & Farmasi & $\begin{array}{l}\text { Obat-obatan mempunyai sifat } \\
\text { racun rendah hingga tinggi, } \\
\text { terdapat jenis bahan kimia di } \\
\text { instalasi farmasi yang } \\
\text { mempunyai sifat reaktif, dan } \\
\text { berpotensi menimbulkan } \\
\text { pencemaran lingkungan. }\end{array}$ & Instalasi farmasi & $\begin{array}{l}\text { Obat-obat yang telah } \\
\text { kadaluarsa dikembali- } \\
\text { kan ke pihak yang } \\
\text { menyuplai obat }\end{array}$ \\
\hline
\end{tabular}


Pemberian simbol merupakan hal yang harus dilakukan sesuai dengan karakteristik dan jenis LB3 yang dihasilkan. Pelekatan simbol dan label harus dapat menerangkan jenis dan karakteristik LB3 yang terdapat dalam wadah tersebut. Pelekatan label dan simbol harus dipasang mengikuti aturan yang ada, baik bentuk dan ukurannya harus tertulis jelas dan terbaca. Pemberian simbol dan label ditempelkan dalam area kerja aktivitas sarana pelayanan kesehatan. LB3 yang mempunyai karakteristik lebih dari satu jenis, maka simbol yang dipasang merupakan simbol dari karakteristik yang dominan. Alat angkut LB3 wajib diberikan simbol yang memenuhi persyaratan, sebagaimana persyaratan yang dimaksud, sebagai berikut: (a) dokumentasi berupa gambar alat angkut yang berwarna tampak dari bagian depan, belakang, kiri, dan kanan; (b) terlihat dengan jelas identitas nama kendaraan (nama perusahaan); dan (c) nomor telepon perusahaan wajib tercantum permanen. Simbol yang tercantum dalam alat angkut LB3 tersebut harus dipasang dengan jelas supaya kalua terjadi kecelakaan maka secara cepat dapat ditanggulangi dengan cara menghubungi identitas yang ada dalam kendaraan tersebut [9-14].

RSGM Unpad menerapkan pemilahan limbah medis menjadi dua yaitu limbah infeksius dan limbah jarum suntik. Limbah infeksius disimpan pada wadah berwarna kuning, sedangkan limbah jarum suntik, infusan, botol obat yang bersifat benda tajam dan infeksius dimasukan kedalam wadah safetybox. Wadah tersebut berbentuk persegi panjang dengan dimensi 15 × 15 × $30 \mathrm{~cm}$. Wadah disimpan di setiap poli, ruang tunggu, dan dental unit seperti disajikan pada Gambar 1 dan 2.

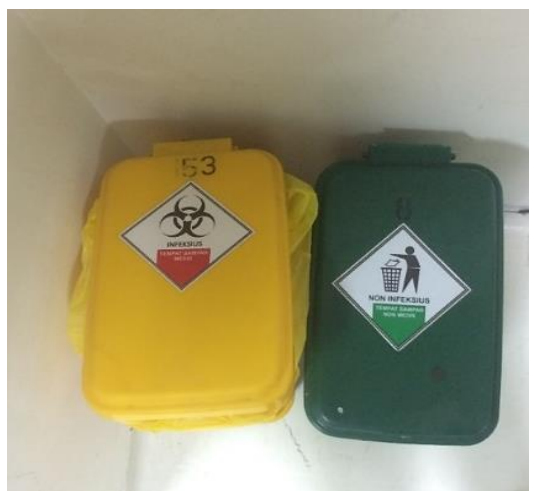

Gambar 1. Pewadahan LB3 di RSGM Unpad Sumber: Hasil pengamatan, 2019

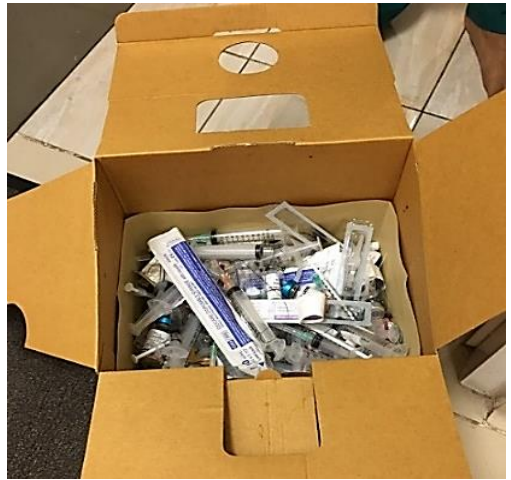

Gambar 2. Pewadahan benda tajam di RSGM Unpad Sumber: Hasil pengamatan, 2019

Proses pewadahan LB3 di RSGM Unpad dianalisis dengan membandingkan antara kondisi di lokasi penelitian dengan peratutan berdasarkan Permen LHK No 56 Tahun 2015. Berdasarkan hasil analisis seperti disajikan pada Tabel 2 terlihat bahwa pewadahan sudah sesuai dengan ketentuan dengan persen kesesuaian sebesar $100 \%$ karena telah sesuai dengan 8 persyaratan pewadahan. Tabel 3 menampilkan pelekatan label pada wadah LB3 di RSGM Unpad.

Tabel 2. Perbandingan pewadahan LB3 di RSGM Unpad dengan Permen LHK No 56/2015

\begin{tabular}{|c|c|c|c|}
\hline No & $\begin{array}{l}\text { Persyaratan Pewadahan Sesuai } \\
\text { Permen LHK No 56/ } 2015\end{array}$ & $\begin{array}{l}\text { Kondisi di Lokasi } \\
\text { Penelitian }\end{array}$ & Keterangan \\
\hline 1 & $\begin{array}{l}\text { Limbah padat dipisahkan sesuai } \\
\text { jenis dan karakteristik LB3 }\end{array}$ & $\begin{array}{l}\text { LB3 telah dipisahkan } \\
\text { antara limbah infeksius } \\
\text { dan benda tajam seperti } \\
\text { disajikan pada Gambar } 1 \\
\text { dan } 2 \text {. }\end{array}$ & $\begin{array}{l}\text { Telah sesuai hanya terdapat } 3 \text { wadah } \\
\text { yaitu wadah untuk limbah infeksius dan } \\
\text { wadah sampah domestik, dan safety box }\end{array}$ \\
\hline 2 & $\begin{array}{l}\text { LB3 yang dihasilkan harus } \\
\text { dipisahkan antara limbah medis } \\
\text { dan non medis }\end{array}$ & $\begin{array}{l}\text { Limbah yang dihasilkan } \\
\text { telah dipisahkan menjadi } 2 \\
\text { yaitu limbah medis yang } \\
\text { termasuk kategori LB3 } \\
\text { dikelola secara khusus dan } \\
\text { limbah non medis seperti } \\
\text { disajikan pada Gambar } 1 \\
\text { dan } 2 \text {. }\end{array}$ & $\begin{array}{l}\text { Telah sesuai limbah dipisahkan antara } \\
\text { limbah medis dan limbah non medis }\end{array}$ \\
\hline 3 & $\begin{array}{l}\text { Pemilahan sedekat mungkin } \\
\text { dengan sumber }\end{array}$ & $\begin{array}{l}\text { Pemilahan langsung } \\
\text { dilakukan di sumber } \\
\text { penghasil limbah }\end{array}$ & $\begin{array}{l}\text { Telah sesuai diberikan dua wadah untuk } \\
\text { limbah domestik dan Infeksius yang } \\
\text { berdekatan untuk memudahkan } \\
\text { pemilahan }\end{array}$ \\
\hline
\end{tabular}




\begin{tabular}{|c|c|c|c|}
\hline No & $\begin{array}{l}\text { Persyaratan Pewadahan Sesuai } \\
\text { Permen LHK No 56/ } 2015\end{array}$ & $\begin{array}{l}\text { Kondisi di Lokasi } \\
\text { Penelitian }\end{array}$ & Keterangan \\
\hline 4 & $\begin{array}{l}\text { Limbah padat diwadahi sesuai } \\
\text { jenis dan karakteristik } \\
\text { berdasarkan warna }\end{array}$ & $\begin{array}{l}\text { Sudah dipilah sesuai } \\
\text { karakterististik } \\
\text { berdasarkan warna }\end{array}$ & $\begin{array}{l}\text { Telah sesuai terdapat dua wadah sesuai } \\
\text { yang berdekatan dan memiliki simbol } \\
\text { untuk membedakan karakteristik limbah } \\
\text { yang akan dibuang }\end{array}$ \\
\hline 5 & $\begin{array}{l}\text { Volume limbah paling tinggi } \\
75 \% \text { wadah }\end{array}$ & $\begin{array}{l}\text { Masih ditemukan melebihi } \\
\text { wadah }\end{array}$ & $\begin{array}{l}\text { Belum sesuai limbah berisi dari kegiatan } \\
\text { medis melebihi } 75 \% \text { dari volume wadah } \\
\text { limbah medis }\end{array}$ \\
\hline 6 & $\begin{array}{l}\text { Wadah limbah kokoh, kedap, anti } \\
\text { air bocor, tidak mudah dibuka, } \\
\text { dan rusak }\end{array}$ & $\begin{array}{l}\text { Wadah limbah terbuat dari } \\
\text { plastik khusus yang kuat } \\
\text { anti air dan tidak mudah } \\
\text { bocor ataupun rusak }\end{array}$ & $\begin{array}{l}\text { Telah sesuai wadah limbah terbuat dari } \\
\text { plastik yang kuat yang tidak } \\
\text { memungkinkan untuk bocor }\end{array}$ \\
\hline 7 & $\begin{array}{l}\text { Letak pemilahan limbah infeksius } \\
\text { dan non infeksius berdekatan }\end{array}$ & $\begin{array}{l}\text { Letak antara pemilahan } \\
\text { limbah infeksius dan non } \\
\text { infeksius berdekatan }\end{array}$ & $\begin{array}{l}\text { Telah sesuai diletakan bersampingan } \\
\text { antara wadah limbah infeksius dengan } \\
\text { wadah non infeksius }\end{array}$ \\
\hline 8 & $\begin{array}{l}\text { Tempat LB3 dilengkapi dengan } \\
\text { simbol dan label sesuai jenis atau } \\
\text { karakteristik LB3 yang dihasilkan }\end{array}$ & $\begin{array}{l}\text { Wadah dilengkapi dengan } \\
\text { simbol dan label }\end{array}$ & $\begin{array}{l}\text { Telah sesuai simbol terletak di atas } \\
\text { wadah untuk memudahkan untuk } \\
\text { mengetahui karakteristik limbah yang } \\
\text { akan dibuang }\end{array}$ \\
\hline
\end{tabular}

Sumber: Hasil pengamatan, 2019

Tabel 3. Perbandingan pelekatan simbol dan label di RSGM Unpad dengan Permen LHK No 56/2015

\begin{tabular}{cll}
\hline No & $\begin{array}{c}\text { Persyaratan Pewadahan Sesuai } \\
\text { Permen LHK No 56/2015 }\end{array}$ & \multicolumn{1}{c}{ Kondisi di Lokasi Penelitian } \\
\hline 1 & Limbah Infeksius & $\begin{array}{l}\text { Pelekatan simbol pada wadah LB3 telah di pasang label } \\
\text { sesuai dengan ketentuan. } \\
\text { Pemasangan label limbah non-infeksius telah sesuai dengan } \\
\text { ketentuan. Simbol terletak di atas atau tutup wadah }\end{array}$ \\
3 & Limbah Non-Infeksius & $\begin{array}{l}\text { Limbah infeksius memiliki simbol hazardous di depan } \\
\text { wadah Terdapat beberapa label yang rusak karena terkena } \\
\text { air sehingga tidak jelas terbaca }\end{array}$ \\
\hline
\end{tabular}

LB3 yang dihasilkan harus dikumpulkan dan disimpan di TPS yang aman dari berbagai gangguan manusia dan binatang serta ditumpuk dengan rapi sampai LB3 yang dihasilkan tersebut diangkut oleh perusahaan pengangkut yang berizin. Berdasarkan peraturan penghasil LB3 harus melalukan penyimpanan dengan cara-cara sebagai berikut, yaitu (a) menyimpan LB3 di TPS khusus yang tidak boleh tercampur dengan limbah dan barang lain; (b) menggunakan wadah LB3 sesuai kelompok LB3 yang dihasilkan misal infeksius, benda tajam, dan lain-lain; (c) menggunakan wadah penampung LB3 dengan warna tertentu sesuai dengan karakteristik LB3 yang dihasilkan; dan (d) melekatkan simbol dan label LB3 pada setiap wadah LB3 sesuai karakteristik LB3 [8-14]. LB3 yang telah melalui proses pengurangan dan pemilahan wajib disimpan di TPS LB3. Penyimpanan LB3 paling lama 2 hari, pada ruangan yang memiliki suhu kurang dari $0^{\circ} \mathrm{C}$; atau 90 hari, pada ruangan dengan suhu $\leq 0^{\circ} \mathrm{C}$, sejak LB3 ditimbulkan. LB3 disimpan di TPS paling lama 90 hari untuk LB3 yang dihasilkan sebesar $\geq 50 \mathrm{~kg}$ per hari; atau 180 hari, untuk LB3 yang dihasilkan $\leq 50 \mathrm{~kg}$ per hari untuk LB3 kategori 1 sejak limbah tersebut dihasilkan [8-14]. Tabel 4 menyajikan perbandingan TPS LB3 di RSGM Unpad dengan permen LHK No 56 Tahun 2015.

Tabel 4. Perbandingan TPS LB3 di RSGM Unpad dengan PerMen LHK Nomor 56/ 2015

\begin{tabular}{clll}
\hline No & \multicolumn{1}{c}{$\begin{array}{c}\text { Persyaratan Penyimpanan Sesuai } \\
\text { Permen LHK No 56/2015 }\end{array}$} & \multicolumn{1}{c}{$\begin{array}{c}\text { Kondisi di } \\
\text { Lokasi Penelitian }\end{array}$} \\
\hline 1 & $\begin{array}{l}\text { Lantai TPS harus kedap air, terbuat dari } \\
\text { beton/semen/keramik, yang dilengkapi dengan } \\
\text { sistem drainase mudah dibersihkan dengan } \\
\text { desinfektan }\end{array}$ & $\begin{array}{l}\text { Lantai TPS LB3 terbuat dari semen yang kedap air, } \\
\text { disajikan pada Gambar 3a. }\end{array}$ \\
\hline
\end{tabular}




\begin{tabular}{|c|c|c|}
\hline No & $\begin{array}{l}\text { Persyaratan Penyimpanan Sesuai } \\
\text { Permen LHK No 56/2015 }\end{array}$ & $\begin{array}{c}\text { Kondisi di } \\
\text { Lokasi Penelitian }\end{array}$ \\
\hline 2 & $\begin{array}{l}\text { TPS dilengkapi dengan sumber air bersih untuk } \\
\text { proses pembersihan ruangan yang ada }\end{array}$ & $\begin{array}{l}\text { Tersedia sumber air yang berasal dari PDAM Tirta } \\
\text { Wening Kota Bandung. Kondisi kualitas dan } \\
\text { kuantitas air memenuhi dan tersedia setiap saat } \\
\text { seperti disajikan pada Gambar } 3 \text { b. }\end{array}$ \\
\hline 3 & $\begin{array}{l}\text { TPS ditempatkan pada lokasi yang memiliki } \\
\text { jalan masuk yang mudah untuk penyimpanan } \\
\text { limbah }\end{array}$ & $\begin{array}{l}\text { Jalan masuk ke TPS LB3 RSGM Unpad baik dan } \\
\text { dapat dengan mudah untuk dimasuki oleh alat } \\
\text { pengangkut LB3. }\end{array}$ \\
\hline 4 & $\begin{array}{l}\text { Harus dikunci untuk menghindari keluar masuk } \\
\text { orang yang tidak berkepentingan }\end{array}$ & $\begin{array}{l}\text { TPS LB3 terkunci dengan baik dan rapat sehingga } \\
\text { tidak bisa sembarangan orang bisa masuk sehingga } \\
\text { TPS LB3 terjaga dengan aman seperti disajikan } \\
\text { pada Gambar 3c. }\end{array}$ \\
\hline 5 & $\begin{array}{l}\text { TPS ditempatkan pada posisi yang mudah } \\
\text { diakses oleh kendaraan pengangkut limbah dan } \\
\text { disertai dengan jalan masuk yang memadai }\end{array}$ & $\begin{array}{l}\text { TPS LB3 mudah diakses oleh kendaraan } \\
\text { pengangkut limbah dengan jalan akses yang } \\
\text { memadai }\end{array}$ \\
\hline 6 & $\begin{array}{l}\text { TPS mempunyai pelindung dari cuaca seperti } \\
\text { sinar matahari, hujan, angin, banjir dll }\end{array}$ & $\begin{array}{l}\text { TPS B3 yang ada di RSGM Unpad aman terlindung } \\
\text { dari kondisi cuaca seperti angin kencang, dan } \\
\text { banjir, dll. }\end{array}$ \\
\hline 7 & $\begin{array}{l}\text { TPS terjaga dari masuknya binatang seperti } \\
\text { serangga, tikus, dan burung }\end{array}$ & $\begin{array}{l}\text { TPS B3 aman dari masuknya serangga dan burung } \\
\text { karena ruangan tertutup rapat, selain itu dilakukan } \\
\text { pemeriksaan kondisi jendela dan langit-langit serta } \\
\text { bagian bangunan lainnya secara periodik }\end{array}$ \\
\hline 8 & $\begin{array}{l}\text { TPS dilengkapi dengan alat sirkulasi udara } \\
\text { seperti ventilasi dan memiliki system } \\
\text { pencahayaan yang baik sehingga kondisi } \\
\text { ruangan tidak pengap dengan pencahayaan yang } \\
\text { cukup terang }\end{array}$ & $\begin{array}{l}\text { Terdapat alat penghisap udara (exhaust fan) yang } \\
\text { bekerja dengan baik sehingga sirkulasi udara di } \\
\text { dalam TPS LB3 berjalan bagus tidak pengap. } \\
\text { Terdapat kekurangan yaitu sistem pencahayaan } \\
\text { yang harus diperbaiki. }\end{array}$ \\
\hline 9 & $\begin{array}{l}\text { TPS harus ditempatkan pada lokasi yang jauh } \\
\text { dari tempat penyimpanan atau penyiapan } \\
\text { makanan seperti kantin }\end{array}$ & $\begin{array}{l}\text { TPS B3 berjarak jauh dengan area makanan. Jarak } \\
\text { antara TPS Limbah medis dengan kantin sekitar } \\
300 \text { meter }\end{array}$ \\
\hline 10 & $\begin{array}{l}\text { Dinding, lantai, dan langit-langit fasilitas TPS } \\
\text { harus terpelihara sehingga bersih dan rapi. Harus } \\
\text { dilakukan pembersihan lantai setiap hari }\end{array}$ & $\begin{array}{l}\text { Keadaan dinding, lantai, dan langit-langit di dalam } \\
\text { TPS B3 medis yang terdapat di RSGM Unpad } \\
\text { dalam keadaan bersih. Hal yang perlu ditingkatkan } \\
\text { untuk melakukan pembersihan lantai setiap hari. }\end{array}$ \\
\hline
\end{tabular}

\section{Sumber: Hasil pengamatan, 2019}

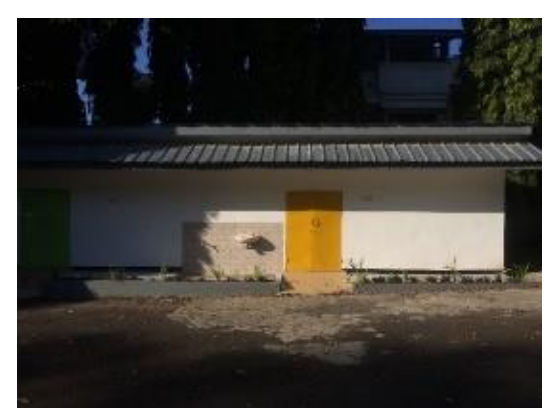

a. Bangunan TPS LB3

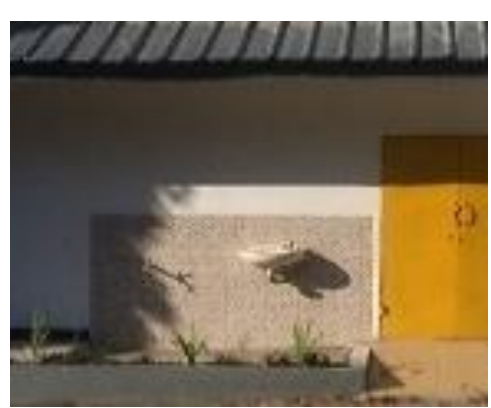

b. Sumber air di TPS LB3

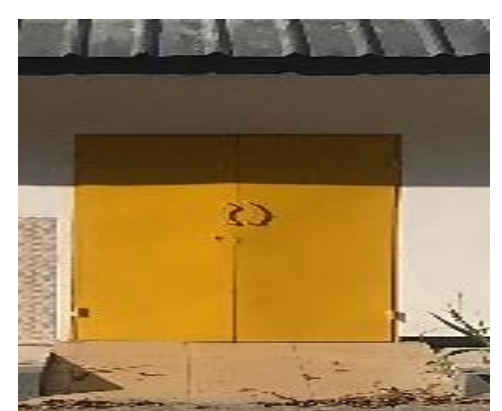

c. Pintu di TPS LB3

Gambar 3. TPS LB3 di RSGM Unpad

Sumber: Hasil pengamatan, 2019

\section{Pengangkutan insitu}

Proses pengelolaan LB3 yang penting lainnya yaitu pengangkutan. Pengangkutan yang terjadwal dengan baik menjadi faktor penting dalam pengelolaan LB3 di RSGM Unpad. Pengangkutan terdiri dari insitu dan eksitu. Pengangkutan insitu dilaksanakan setiap hari pada sore hari saat aktivitas tidak terlalu ramai. LB3 yang dihasilkan tidak boleh dibiarkan menumpuk pada suatu wadah. Hal ini diperlukan untuk mengurangi risiko terpaparnya pekerja oleh LB3 yang bersifat infeksius. Diperlukan pelibatan dan kesadaran seluruh pemangku kepentingan seperti dokter, asisten dokter, perawat, staf administrasi, serta bagian pengelolaan LB3, fasilitas pelayanan kesehatan, bagian housekeeping, maupun kerjasama antar personil pelaksana mengenai diperlukannya pengelolaan LB3 yang baik dan benar sesuai dengan 
peraturan yang berlaku. Cara pandang yang sama mengenai pengelolaan LB3 di semua pemangku kepentingan akan menghindari dampak pencemaran LB3 di lokasi kegiatan terhadap manusia [8-14].

Alat angkut yang dipergunakan bisa berupa troli/wadah beroda atau alat lainnya yang memenuhi persyaratan sebagai berikut: (1) wadah yang dipergunakan tidak sulit untuk bongkar-muat LB3, (2) tahan goresan limbah benda tajam seperti jarum suntik bekas, dan (3) mudah dibersihkan. Pekerja yang bersangkutan dengan LB3 harus menggunakan alat pelindung diri yang memenuhi standar kesehatan dan keselamatan kerja. Pengangkutan LB3 secara insitu harus dilakukan secara rutin dan terjadwal. Pola pengangkutan harus tergambar dengan jelas sehingga setiap sumber limbah dapat terangkut setiap hari dan tidak terjadi penumpukan LB3. Proses pengangkutan harus didukung oleh petugas yang bertanggungjawab mengumpulkan LB3 dari sumber limbah, tidak boleh terjadi tumpeng tindih pengaturan pengambilan LB3 semua harus diatur secara jelas. Perencanaan jalur pengangkutan LB3 harus dibuat dengan memperhatikan bahwa jalur yang dibuat menghindari daerah yang dilalui banyak orang atau barang. Hal lainnya yang harus diperhatikan yaitu rute pengumpulan harus dimulai dari area yang paling jauh menuju lokasi yang terdekat dengan TPS [8-14].

Pengangkutan yang dilakukan oleh pengelola lain atau pihak ketiga (outsourcing), maka pengelola pengangkutan harus mendapatkan persetujuan yang diterbitkan oleh kepala instansi lingkungan hidup setempat. Persyaratan yang wajib dimiliki pengangkut yaitu memiliki alat angkut LB3 yang telah mendapatkan izin, alat pengangkut dipasangkan simbol LB3 medis dan dilengkapi manifest limbah medis. Manifest tersebut memuat informasi mengenai kode manifest, sumber, karakteristik, dan jumlah LB3 yang diangkut, identitas pengirim, pengangkut, dan penerima limbah medis, serta alat angkut limbah medis. Proses pengangkutan LB3 medis di RSGM Unpad telah sesuai dengan persyaratan seperti disajikan pada Tabel 5. Sistem pengangkutan dilakukan setiap hari pada sore hari sekitar pukul 16.00 WIB. Pengangkutan oleh pihak ketiga berizin dilaksanakan pada hari Senin dan Kamis pagi sekitar pukul 10.00 WIB. Pengangkutan dilaksanakan 2 kali seminggu dengan tujuan supaya tidak terjadi penumpukan LB3 di TPS.

Tabel 5. Perbandingan alat angkut eksisting dengan PerMen LHK Nomor 56/2015

\begin{tabular}{|c|c|c|}
\hline No & $\begin{array}{l}\text { Persyaratan Penyimpanan Sesuai } \\
\text { Permen LHK No 56/2015 }\end{array}$ & $\begin{array}{c}\text { Kondisi di } \\
\text { Lokasi Penelitian }\end{array}$ \\
\hline \multicolumn{3}{|c|}{ Alat Angkut Eksitu } \\
\hline 1. & Mudah dilakukan bongkar-muat Limbah & $\begin{array}{l}\text { Alat angkut yang dipergunakan telah sesuai } \\
\text { dengan peraturan yang berlaku dimana mudah } \\
\text { dilakukan bongkar muat LB3 }\end{array}$ \\
\hline 2. & $\begin{array}{l}\text { Alat angkut yang dipergunakan baik itu berupa } \\
\text { troli/bin/tong yang digunakan kuat dan tahan goresan } \\
\text { limbah tajam seperti jarum suntik bekas dan gancu yang } \\
\text { dipergunakan dalam proses pengangkutan, }\end{array}$ & $\begin{array}{l}\text { Wadah pengangkut LB3 yang digunakan yaitu } \\
\text { Wheel Bin yang tahan goresan limbah benda } \\
\text { tajam. Wheel Bin terbuat dari plastik yang sesuai } \\
\text { dengan arahan dari PerMen LHK Nomor } 56 / 2015 \\
\text { seperti disajikan pada Gambar } 4 \text { a. }\end{array}$ \\
\hline 3. & Mudah dibersihkan & $\begin{array}{l}\text { Wheel Bin mudah dibersihkan karena dapat } \\
\text { dibongkar }\end{array}$ \\
\hline \multicolumn{3}{|c|}{ Alat Angkut Eksitu } \\
\hline & $\begin{array}{l}\text { Menggunakan alat angkut telah mendapatkan izin } \\
\text { pengolahan }\end{array}$ & $\begin{array}{l}\text { Pihak ketiga yang mengelola LB3 dari RSGM } \\
\text { Unpad yaitu PT Jasa Medivest telah memiliki izin } \\
\text { pengolahan LB3 yang dikeluarkan olek KLHK } \\
\text { Republik Indonesia. Perusahaan telah dilengkapi } \\
\text { dengan ISO 9001, ISO 14001, serta ISO 18001 } \\
\text { serta memperoleh Proper biru dari KLHK } \\
\text { Republik Indonesia. }\end{array}$ \\
\hline 2. & $\begin{array}{l}\text { Ditempatkan dalam bak permanen tertutup di belakang } \\
\text { pengendara }\end{array}$ & $\begin{array}{l}\text { Diangkut dengan menggunakan mobil box } \\
\text { tertutup sehingga aman dibawa dan tidak } \\
\text { menyebabkan pengendara terkontaminasi oleh } \\
\text { LB3 medis seperti disajikan pada Gambar } 4 \mathrm{~b} \text {. }\end{array}$ \\
\hline 3. & Pelekatan simbol pada wadah & $\begin{array}{l}\text { Menggunakan troli yang tebal terbuat dari plastic } \\
\text { khusus untuk LB3 seperti yang disyaratkan oleh } \\
\text { PerMen LHK Nomor 56/2015 seperti disajikan } \\
\text { pada Gambar 4a. }\end{array}$ \\
\hline 4. & Dilengkapi Manifest & $\begin{array}{l}\text { Setiap pengangkutan dilengkapi manifest LB3 } \\
\text { yang selalu disimpan di bagian administrasi. } \\
\text { Manifest disajikan pada Gambar } 4 \mathrm{c}\end{array}$ \\
\hline
\end{tabular}




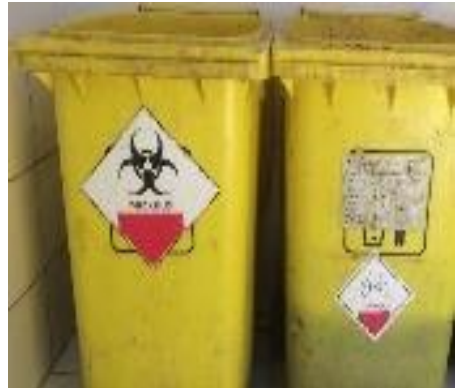

a. Troli

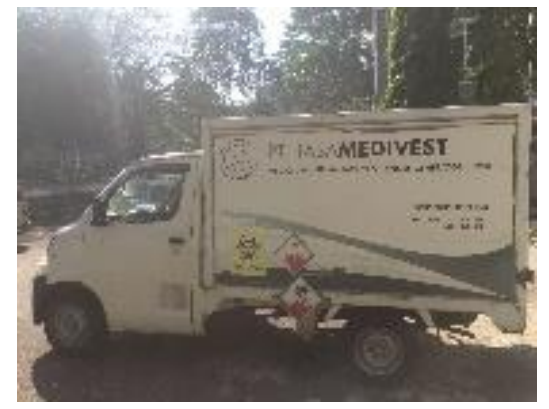

b. Mobil

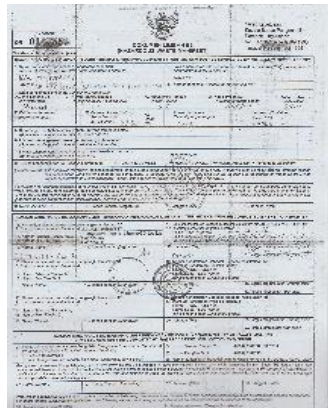

c. Manifest

Gambar 4. Alat angkut di TPS B3 RSGM Unpad

Sumber: Hasil pengamatan, 2019

Berdasarkan hasil analisis penelitian pihak RSGM Unpad mengelola LB3 sesuai dengan arahan dari pemerintah. Hal tersebut terlihat dari sistem pewadahan, pengangkutan, penyimpanan, dan pemindahan ke perusahaan lain semua dilaksanakan sesuai dengan persyaratan yang berlaku untuk pengelolaan LB3. dengan baik tetapi masih ada hal-hal yang perlu ditingkatkan yaitu pada proses pemilahan dan pewadahan LB3 yang masih melebihi 75 persen kantong sebaiknya disesuaikan dengan peraturan yang mengharuskan bahwa jumlah sampah tidak boleh melebihi 75 persen bagian karena akan beresiko sampah tercecer dan tidak tertutup secara sempurna. Pelekatan simbol dan label pada wadah dan TPS LB3 sudah dipasang sesuai dengan baik tetapi hal yang perlu ditingkatkan yaitu harus melakukan penggantian label yang tidak dapat terbaca. Hal tersebut kalau tidak segera diganti akan menyebabkan kesalahan informasi mengenai LB3 tersebut. TPS B3 telah tersedia dengan baik dan memenuhi persyaratan hanya perlu disempurnakan dengan melengkapi pendingin sehingga suhu mencapai $0^{\circ} \mathrm{C}$ dan memperbaiki ventilasi supaya sinar matahari dapat masuk ke seluruh ruangan TPS LB3 serta membangun saluran drainase yang baik.

Pengangkutan LB3 insitu telah dikelola dengan baik sehingga tidak terdapat tumpukan LB3 yang tidak dikelola di sekitar lokasi RSGM Unpad. Pengangkutan eksitu telah dikerjakan berdasarkan persyaratan yang berlaku seperti pengangkutan dilaksanakan secara rutin sehingga tidak terjadi penumpukan serta proses pengangkutan dilakukan sesuai aturan. Hal yang harus diperbaiki yaitu proses pengangkutan LB3 harus dilakukan secara periodik dengan jadwal yang tetap. Hal tersebut menyebabkan tidak terjadi penumpukan LB3 di TPS.

Pengelolaan LB3 di RSGM Unpad telah dilakukan secara baik dan sesuai dengan persyaratan yang berlaku. Hal yang sama juga telah dilakukan oleh RSUD dr Drajat Prawiranegara Kabupaten Serang [1], RSUD Dr. Soetomo Surabaya [15], RS di Kota Batam [16], dan PT X [17]. Berdasarkan hal tersebut dapat ditarik kesimpulan bahwa instansi penghasil LB3 di sejumlah RS di Indonesia telah patuh dan berusaha memenuhi semua persyaratan yang ditetapkan dalam pengolahan LB3. Limbah yang dihasilkan dikelola mulai dari pewadahan di sumber penghasil LB3, pelekatan label dan simbol, selanjutnya proses pengangkutan dan penyimpanan sementara di TPS. Pengangkutan LB3 oleh pihak ketiga menggunakan perusahaan yang telah memiliki izin dari KLHK Republik Indonesia sehingga LB3 yang diangkut terjamin pengelolaannya dan tidak akan mencemari lingkungan. Hal tersebut menunjukan bahwa penghasil LB3 memiliki kepedulian yang besar untuk turut serta melakukan pengelolaan lingkungan hidup serta pembangunan berkelanjutan.

\section{Kesimpulan}

Sumber LB3 di RSGM Unpad berasal dari kegiatan pelayanan medis, penunjang medis, dan aktivitas dokter dan asistennya. LB3 telah dikelola telah sesuai PerMen LHK No 56/2015 seperti membedakan karakteristiknya berdasarkan warna, pewadahan dibagi dua jenis yaitu limbah infeksius ditempatkan pada safetybox, dan limbah domestik ditempatkan pada tempat sampah terpisah. Limbah domestik dikumpulkan pada TPS dan diangkut ke TPA Sarimukti Provinsi Jawa Barat. Proses pengumpulan LB3 di RSGM Unpad dilakukan setiap hari. Limbah diangkut oleh petugas kebersihan tiap ruangan dengan kantong plastik berwarna kuning. Pengangkutan LB3 oleh pihak ketiga dilakukan seminggu dua kali, biasanya pada hari Senin dan Kamis. Hal yang harus ditingkatkan dalam pengelolaan LB3 di RSGM Unpad yaitu memperbaiki label pada wadah LB3 yang sudah tidak dapat terbaca. Pengumpulan LB3 medis menggunakan kantong plastik tidak melebihi $75 \%$ dari volume kantong tersebut. TPS harus dilengkapi dengan pendingin ruangan supaya LB3 yang tersimpan berada pada 
ruangan dengan suhu $0^{\circ} \mathrm{C}$. Hal lain yang harus disempurnakan yaitu pembuatan saluran drainase yang berfungsi untuk menghindari genangan di sekitar TPS LB3.

\section{Daftar Pustaka}

[1] A. Ariesmayana dan Hajali "Studi Pengelolaan Limbah B3 di RSUD dr Drajat Prawiranegara Kabupaten Serang" Jurnal Serambi Engineering, Volume III, No.2, Agustus 2018.

[2] B. Bassey, C. MO-Benka and H. Aluyi, "Characterization and management of solid medical wastes in the Federal Capital Territory," Abuja Nigeria, vol. 1, pp. 58-63, 2006.

[3] D. Enri, Diktat Kuliah TL-3204 Pengelolaan Bahan Berbahaya dan Beracun (B3) Edisi Semester II 2009-2010, Program Studi Teknik Lingkungan ITB, Bandung, 2010.

[4] Departemen Kesehatan Republik Indonesia, Pedoman Sanitasi Rumah Sakit di Indonesia, Direktorat Jenderal PPM \& PPL dan Direktorat Jenderal Pelayanan Medik, Jakarta, 2002.

[5] Peraturan Pemerintah nomor 93 Tahun 2015 Tentang Rumah Sakit Pendidikan.

[6] Departemen Kesehatan Republik Indonesia, Profil Kesehatan Republik Indonesia, Depkes RI, Jakarta, 2006.

[7] Keputusan Menteri Kesehatan Republik Indonesia Nomor 1204 Tahun 2004 tentang Persyaratan Kesehatan Lingkungan Rumah Sakit.

[8] RSGM Unpad. 2019, Upaya Pengelolaan Lingkungan dan Upaya Pemantauan Lingkungan Rumah Sakit, Bandung.

[9] Peraturan Menteri Lingkungan Hidup dan Kehutanan Republik Indonesia Nomor 56 Tahun 2015 tentang Tata Cara dan Persyaratan Teknis Pengelolaan Limbah Bahan Berbahaya dan Beracun dari Fasilitas Pelayanan Kesehatan.

[10] Keputusan Kepala Bapedal No. KEP-01/BAPEDAL/09/1995 Tentang Tata Cara dan Persyaratan Teknis Penyimpanan dan Pengumpulan Limbah Bahan Berbahaya dan Beracun.

[11] Keputusan Kepala Bapedal No. KEP-02/BAPEDAL/09/1995 Tentang Dokumen Limbah Bahan Berbahaya dan Beracun.

[12] Keputusan Kepala Bapedal No. KEP-03/BAPEDAL/09/1995 Tentang Persyaratan Teknis Pengelolaan Limbah Bahan Berbahaya dan Beracun.

[13] Peraturan Menteri Negara Lingkungan Hidup Republik Indonesia Nomor 02 Tahun 2008 Tentang Pemanfaatan Limbah Bahan Berbahaya dan Beracun.

[14] Peraturan Menteri Negara Lingkungan Hidup Republik Indonesia Nomor 14 Tahun 2013 Tentang Simbol dan Label Limbah Bahan Berbahaya dan Beracun.

[15] Purwanti dan A. Ajeng, "Pengelolaan Limbah Padat Bahan Berbahaya dan Beracun (B3) Rumah Sakit di RSUD Dr. Soetomo Surabaya," J. Kesehatan Lingkungan, Vol. 10(3), hal. 291-298, 2018.

[16] S. S. Siddik dan E. Wardhani, "Pengelolaan Limbah B3 Di Rumah Sakit X Kota Batam," J. Serambi Engineering, Volume V (1), hal. 760-767, 2020.

[17] S.A. Fajriyah dan E. Wardhani "Evaluasi Pengelolaan Limbah Bahan Berbahaya dan Beracun (B3) di PT. X,” J. Serambi Engineering, Volume V(1), hal. 711- 719, 2020. 